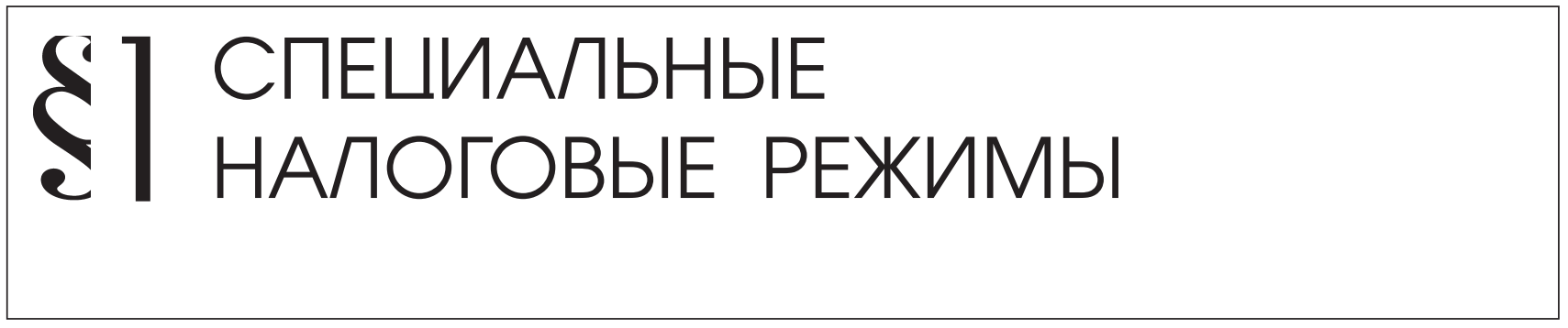

И.В. Оробинская

\title{
ОСОБЕННОСТИ И АНАЛИЗ ПРИМЕНЕНИЯ РАЗЛИЧНЫХ РЕЖИМОВ НАЛОГООБЛОЖЕНИЯ ДЛЯ СЕЛЬСКОХОЗЯЙСТВЕННЫХ ТОВАРОПРОИЗВОДИТЕЛЕЙ В РОССИИ
}

Аннотация: России сельское хозяйство подлежит налогообложению наряду с другими секторами экономики. В то же время традиционно аграрному сектору предоставляются определенные налоговые льготы, а также особый режим налогообложения, связанный со специфическими особенностями производства, а именно сезонностью, зависимостью от погодного фактора, специилизаичей, особенностями средств производства.

На всем протяжении периода реформирования экономики государство пыталось создать для сельскохозяйственных товаропроизводителей механизм налогообложения, максимально учитыввющий особенности их производства.

Таким образом, в статье выделены особенности и дан глубокий анализ положительных отрицательных сторон применения различных режимов налогообложеня для сельскохозяйственных товаропроизводителей в РФ.

Ключевые слова: Налоги и налогообложение, Налогообложение, ЕСХН, Налоговые платежи, Налоговое бремя, Сельхозтоваропроизводители, НДС, Налог на прибыль, Земельный налог, Транспортный налог

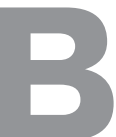

России сельское хозяйство подлежит налогообложению наряду с другими секторами экономики. В то же время традиционно аграрному сектору предоставляются определенные налоговые льготы, а также особый режим налогообложения, связанный со специфическими особенностями производства, а именно сезонностью, зависимостью от погодного фактора, специализацией, особенностями средств производства.
На всем протяжении периода реформирования экономики государство пыталось создать для сельскохозяйственных товаропроизводителей механизм налогообложения, максимально учитывающий особенности их производства.

В связи с этим, 1 января 2004 г. были введены в действие изменения в гл. 26.1 НК РФ «Система налогообложения для сельскохозяйственных товаропроизводителей (ЕСХН)», принципиально отлича- 


\section{Налоги и налогообложение - №2(104) • 2013}

ющиеся от ранее действующей редакции. Так, единый сельскохозяйственный налог был переведен на федеральный уровень, а с 2005 г. налог переведен в разряд специальных режимов налогообложения.

Изменения в налоговом законодательстве предоставили предприятиям агропромышленного комплекса добровольный порядок перехода с общего режима налогообложения на уплату единого сельскохозяйственного налога с заменой ряда традиционных налогов (налог на добавленную стоимость, налог на имущество организаций, налог на прибыль организаций) единым налогом.

Следует отметить, что влияние данной трансформации показывает величина налоговых поступлений в бюджетную систему России от аграрного сектора экономики.

Для более детального анализа поступлений от специальных режимов следует обратиться к таблице 2, где видно, что больше половины платежей приходится в основном на упрощенную систему налогообложения, так в 2011 году поступления от УСН со- ставили 67,9 \% дохода от специальных налоговых режимов.

Единый сельскохозяйственный налог в итоговой сумме от поступлений по специальным режимам составляет всего лишь $1 \%$. Этот факт можно объяснить тем, что данный режим реализует функцию поддержания отрасли сельского хозяйства. Несмотря на незначительные поступления, наблюдается тенденция к увеличению собираемости средств от данного вида режимов, так в 2011 году доход от ЕСХН составил 3,88 млрд. руб., что более чем в 5 раз превысило поступления 2005 года. Следует отметить, что такой рост произошел за счет увеличения числа плательщиков ЕСХН, так, например, по Воронежской области в 2011 году их число составило 2084 (ед./чел.), что на 691 плательщика больше по сравнению с 2005 годом. Хотя в 2009 году произошло их незначительное снижение на 6 (ед./чел.) до 1811 (ед./чел.). Впрочем аналогичная ситуация наблюдалась и по остальным налогам, что связано с масштабностью влияния кризисных явлений на экономику России.

Таблицуа 1

Удельный вес и структура налоговых платежей в консолидированном бюджете РФ в иелом по экономике в 2005-2011 г2., млрд. руб.

\begin{tabular}{|c|c|c|c|c|c|c|c|c|c|c|c|c|c|c|}
\hline \multirow{3}{*}{$\begin{array}{c}\text { Наимено- } \\
\text { вание по- } \\
\text { казателя }\end{array}$} & \multicolumn{14}{|c|}{ Годы } \\
\hline & \multicolumn{2}{|c|}{2005} & \multicolumn{2}{|c|}{2006} & \multicolumn{2}{|c|}{2007} & \multicolumn{2}{|c|}{2008} & \multicolumn{2}{|c|}{2009} & \multicolumn{2}{|c|}{2010} & \multicolumn{2}{|c|}{2011} \\
\hline & $\begin{array}{c}\text { млрд. } \\
\text { руб. }\end{array}$ & $\%$ & $\begin{array}{c}\text { млрд. } \\
\text { руб. }\end{array}$ & $\%$ & $\begin{array}{c}\text { млрд. } \\
\text { руб. }\end{array}$ & $\%$ & $\begin{array}{l}\text { млрд. } \\
\text { руб. }\end{array}$ & $\%$ & $\begin{array}{c}\text { млрд. } \\
\text { руб. }\end{array}$ & $\%$ & $\begin{array}{c}\text { млрд. } \\
\text { руб. }\end{array}$ & $\%$ & $\begin{array}{c}\text { млрд. } \\
\text { руб. }\end{array}$ & $\%$ \\
\hline $\begin{array}{l}\text { Налог на } \\
\text { прибыль } \\
\text { организа- } \\
\text { ций }\end{array}$ & 1332,9 & 25,21 & 1670,6 & 26,55 & 2172,2 & 29,53 & 2513,0 & 29,74 & 1264,6 & 18,61 & 1878,5 & 22,59 & 2270,3 & 22,47 \\
\hline
\end{tabular}


Специальные налоговые режимы

\begin{tabular}{|c|c|c|c|c|c|c|c|c|c|c|c|c|c|c|}
\hline $\begin{array}{l}\text { Налог } \\
\text { на доходы } \\
\text { физиче- } \\
\text { ских лиц }\end{array}$ & 707,0 & 13,37 & 930,4 & 14,79 & 1266,1 & 17,21 & 1665,8 & 19,71 & 1665,0 & 24,51 & 1789,6 & 21,52 & 1994,9 & 19,74 \\
\hline $\begin{array}{l}\text { Единый } \\
\text { социаль- } \\
\text { ный налог } \\
\text { (в ФБ) }\end{array}$ & 267,9 & 5,07 & 315,9 & 5,02 & 405,0 & 5,51 & 506,8 & 6 & 509,8 & 7,5 & 488,6 & 5,88 & 486,5 & 4,82 \\
\hline $\begin{array}{l}\text { Налог на } \\
\text { добавлен- } \\
\text { ную стои- } \\
\text { мость }\end{array}$ & 1472,3 & 27,85 & 1511,1 & 24,01 & 1424,7 & 19,37 & 1038,7 & 12,29 & 1207,2 & 17,77 & 1421,5 & 17,09 & 1844,9 & 18,26 \\
\hline Акцизы & 253,7 & 4,8 & 270,6 & 4,3 & 289,9 & 3,94 & 314,7 & 3,72 & 327,5 & 4,82 & 455,0 & 5,47 & 603,9 & 5,98 \\
\hline $\begin{array}{l}\text { Налог } \\
\text { на добычу } \\
\text { полезных } \\
\text { ископае- } \\
\text { мых }\end{array}$ & 908,7 & 17,19 & 1162,3 & 18,47 & 1197,4 & 16,28 & 1708,0 & 20,21 & 1053,8 & 15,51 & 1401,6 & 16,86 & 2042,5 & 20,22 \\
\hline $\begin{array}{l}\text { Налог на } \\
\text { имущество } \\
\text { организа- } \\
\text { ций }\end{array}$ & 152,1 & 2,88 & 201,9 & 3,21 & 262,7 & 3,57 & 323,5 & 3,83 & 385,8 & 5,68 & 428,5 & 5,15 & 465,2 & 4,60 \\
\hline $\begin{array}{l}\text { Земельный } \\
\text { налог }\end{array}$ & 48,5 & 0,92 & 45,4 & 0,72 & 68,9 & 0,94 & 80,2 & 0,95 & 95,2 & 1,4 & 118,2 & 1,42 & 44,0 & 0,44 \\
\hline $\begin{array}{l}\text { Специ- } \\
\text { альные } \\
\text { налоговые } \\
\text { режимы }\end{array}$ & 79,0 & 1,49 & 112,6 & 1,79 & 156,0 & 2,12 & 204,3 & 2,42 & 192,5 & 2,83 & 207,7 & 2,50 & 234,1 & 2,32 \\
\hline $\begin{array}{l}\text { Прочие } \\
\text { налоги }\end{array}$ & 65,1 & 1,23 & 71,9 & 1,14 & 113,0 & 1,54 & 96,0 & 1,14 & 92,3 & 1,36 & 126,5 & 1,52 & 117,5 & 1,16 \\
\hline $\begin{array}{l}\text { ИТОГО } \\
\text { налоговых } \\
\text { доходов }\end{array}$ & 5287,2 & $\mathrm{x}$ & 6292,7 & $\mathrm{x}$ & 7355,9 & $\mathrm{x}$ & 8451,0 & $\mathrm{x}$ & 6793,7 & $\mathrm{x}$ & 8315,6 & $\mathrm{x}$ & 10103,8 & $\mathrm{x}$ \\
\hline
\end{tabular}


Таблица 2

Структура налоговых доходов от специальных налоговых режимов в консолидированном бюджете РФ в 2005-2011 г2., млрд. руб.

\begin{tabular}{|c|c|c|c|c|c|c|c|c|c|c|c|c|c|c|}
\hline \multirow{3}{*}{$\begin{array}{c}\text { Наименова- } \\
\text { ние показа- } \\
\text { теля }\end{array}$} & \multicolumn{14}{|c|}{ Годы } \\
\hline & \multicolumn{2}{|c|}{2005} & \multicolumn{2}{|c|}{2006} & \multicolumn{2}{|c|}{2007} & \multicolumn{2}{|c|}{2008} & \multicolumn{2}{|c|}{2009} & \multicolumn{2}{|c|}{2010} & \multicolumn{2}{|c|}{2011} \\
\hline & $\begin{array}{l}\text { млрд. } \\
\text { руб. }\end{array}$ & $\%$ & $\begin{array}{c}\text { млрд. } \\
\text { руб. }\end{array}$ & $\%$ & $\begin{array}{c}\text { млрд. } \\
\text { руб. }\end{array}$ & $\%$ & $\begin{array}{c}\text { млрд. } \\
\text { руб. }\end{array}$ & $\%$ & $\begin{array}{c}\text { млрд. } \\
\text { руб. }\end{array}$ & $\%$ & $\begin{array}{c}\text { млрд. } \\
\text { руб. }\end{array}$ & $\%$ & $\begin{array}{c}\text { млрд. } \\
\text { руб. }\end{array}$ & $\%$ \\
\hline УCHO & 36,5 & 46,2 & 58,7 & 52,13 & 84 & 53,77 & 119,6 & 58,54 & 109,46 & 56,88 & 134,37 & 64,71 & 158,99 & 67,91 \\
\hline ЕНВД & 40,2 & 50,89 & 50,3 & 44,67 & 56,3 & 36 & 63 & 30,84 & 63,92 & 33,21 & 70,61 & 34,00 & 71,25 & 30,43 \\
\hline ЕСХH & 0,7 & 0,89 & 1 & 0,89 & 1,5 & 0,96 & 2,4 & 1,17 & 2,17 & 1,13 & 2,68 & 1,29 & 3,88 & 1,66 \\
\hline $\begin{array}{l}\text { Соглашение } \\
\text { о разделе } \\
\text { продукции }\end{array}$ & 1,6 & 2,03 & 2,6 & 2,31 & 14,5 & 9,27 & 19,3 & 9,45 & 16,9 & 8,78 & - & - & - & - \\
\hline ИТОГО & 79 & 100 & 112,6 & 100 & 156 & 100 & 204,3 & 100 & 192,45 & 100 & 207,65 & 100 & 234,12 & 100 \\
\hline
\end{tabular}

Проведенный сравнительный анализ показал, что предельная величина налогового бремени в аграрном секторе экономики зависит не только от величины совокупного обложения, но и от эффективности производства и финансового со- стояния предприятия. Следовательно, предельный размер налоговой нагрузки должен определяться с учетом отраслевой принадлежности хозяйствующих субъектов и связанной с этим спецификой производственной деятельности.

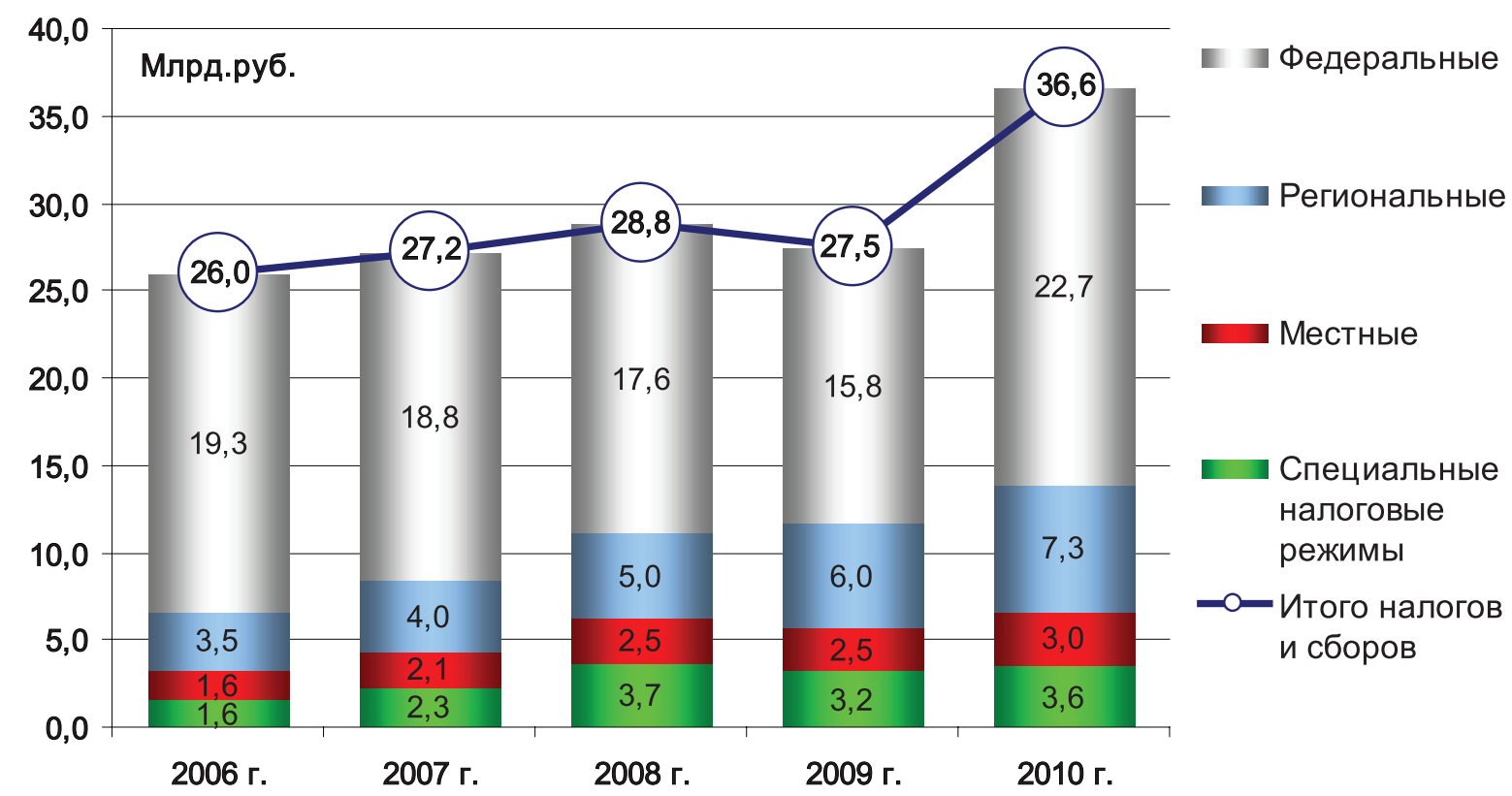

Рисунок 1

Структура налоговых платежей в сельском хозяйстве РФ, млрд. руб. 
Наряду с этим, хотелось бы отметить, что сравнительный анализ двух режимов налогообложения, проведенный на предприятиях, позволил сделать заключение, что налоговая нагрузка предприятий, уплачивающих ЕСХH, снижается примерно в два раза по сравнению с предприятиями, применяющими общий режим налогообложения. Однако следует отметить, что в зависимости от сферы деятельности (производство или переработка сельскохозяйственной продукции) данное снижение имеет различную величину (таблица 3.) Налоговая нагрузка представляет собой долю суммы всех налогов в общих доходах предприятия, учитываемых для целей налогообложения, за финансовый год. возможностью сокращения объемов налоговых расчетов и отчетности, упрощения процедуры налоговых проверок ${ }^{1}$.

Состав обязательных платежей, уплачиваемых сельскохозяйственными товаропроизводителями, по двум различным режимам налогообложения представлен на рисунке 2.

Отрицательной стороной специального режима налогообложения и порядка исчисления ЕСХН является освобождение от уплаты НДС, хотя и позволяет снизить налоговую нагрузку плательщиков. Одновременно освобождение от уплаты НДС приводит к увеличению затрат на сумму НДС по приобретаемым материальным ресурсам: сумма НДС полностью

Таблица 3

Уровни налоговой нагрузки по предприятиям, производящим и перерабатывающчим сельскохозяйственную продукциию

\begin{tabular}{|l|c|c|}
\hline \multicolumn{1}{|c|}{ Группы предприятий } & $\begin{array}{c}\text { Общий режим } \\
\text { налогообложения, \% }\end{array}$ & $\begin{array}{c}\text { Единый сельскохозяй- } \\
\text { ственный налог, \% }\end{array}$ \\
\hline $\begin{array}{l}\text { Предприятия, производящие } \\
\text { сельскохозяйственную продукцию }\end{array}$ & 9,4 & 5,5 \\
\hline $\begin{array}{l}\text { Предприятия, перерабатывающие } \\
\text { сельскохозяйственную продукцию }\end{array}$ & 4,9 & 1,6 \\
\hline
\end{tabular}

Очевидно, что при переходе на уплату ЕСХН уровень налоговой нагрузки заметно уменьшается. Сокращение налоговых платежей, в свою очередь, позволяет снижать расходы организации, и, следовательно, стабилизировать финансовое положение предприятия и корректировать финансовые показатели в лучшую сторону. Кроме того, специальный режим налогообложения привлекателен также относится на издержки, что ведет к удорожанию продукции ${ }^{2}$.

\footnotetext{
${ }^{1}$ Карзаева Н.Н., Медведева Е. / Выбор системы налогообложения сельскохозяйственными предприятиями как фактор финансовой устойчивости // Бухучет в сельском хозяйстве. -2009 . - №9.

${ }^{2}$ Тюпакова Н.Н., Бочарова О.Ф. / Налогообложение сельскохозяйственных товаропроизводителей требует совершенствования // Бухучет в сельском хозяйстве. 2009. - №4.
} 


\section{Налоги и налогообложение - №2(104)•2013}

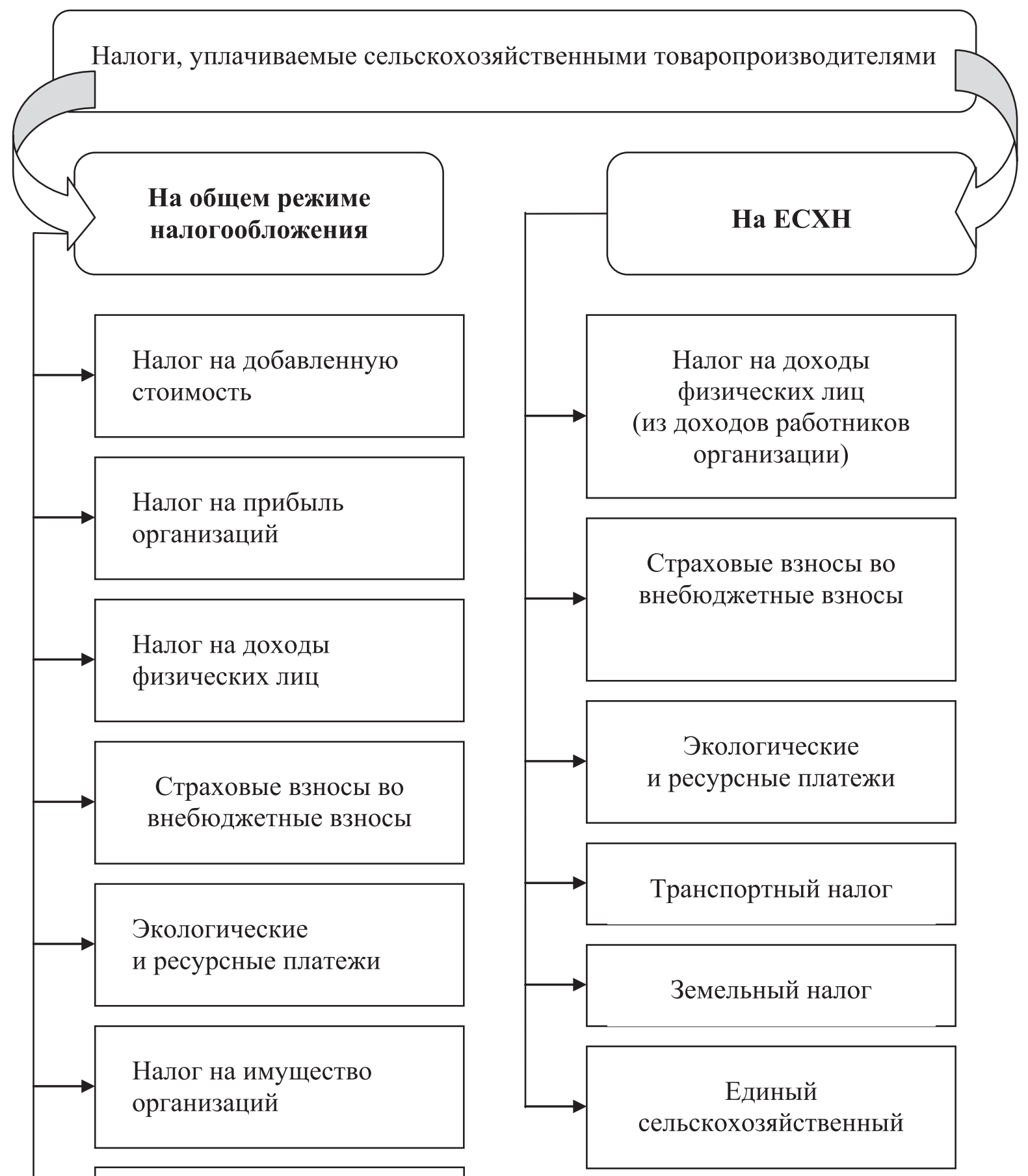

Транспортный налог

Земельный налог

Рисунок 1 - Состав обязательных платежей, уплачиваемых сельскохозяйственными товаропроизводителями по двум системам налогообложения 
Недостатком ЕСХН является дальнейшее увеличение диспаритета цен на сельскохозяйственную и промышленную продукцию. Реализация большинства продовольственных товаров (например, мяса, молока и зерна) облагается по ставке НДС 10\%. В то же время сельхозпредприятия приобретают многие товары (сельхозтехнику, ГСМ, удобрения, ядохимикаты и т.п.), которые облагаются по ставке $18 \%$. Поэтому сумма вычетов по данному налогу у сельхозпредприятий, как правило, превышает сумму начислений. Получается, бюджет зачастую должен вернуть сельхозпредприятию часть НДС, уплаченного поставщикам. У плательщиков ЕСХН обязанности по начислению и уплате НДС нет, но нет и права на вычет этого налога. Для некоторых сельхозпредприятий это может быть существенным минусом ${ }^{3}$.

Несогласованность положений налогового законодательства по уплате налога на добавленную стоимость (НДС) является существенным фактором, который снижает активность сельскохозяйственных организаций при переходе на специальный режим налогообложения ${ }^{4}$.

При переходе на уплату ЕСХН у сельскохозяйственных товаропроизводителей возникает проблема, как строить ценовую политику. Потребителями сельхозпродукции могут быть как физические лица и предприниматели, не являющиеся плательщиками НДС, так и организации и предприниматели - плательщики этого налога. Плательщики ЕСХН не являются плательщиками НДС и не имеют права предъявлять налог покупателям. Поэтому покупатели, применяющие общий режим налогообложения, лишаются права на вычет НДС. Для многих покупателей это может быть невыгодно.

Этот факт особенно отрицательно сказался на предприятиях перерабатывающей промыш-

\footnotetext{
${ }^{3}$ Тоже

${ }^{4}$ Проблемы применения ЕСХН // Бухучет в сельском хозяйстве. -2009 . - №6.
}

ленности (мясокомбинаты, молкомбинаты, хлебокомбинаты, применяющие общий режим налогообложения), что повлекло за собой резкое удорожание продуктов питания.

Фактически происходит скрытое переложение НДС на конечного потребителя, так как он является многоступенчатым налогом и исключение какой либо стадии из обложения, ведет к увеличению цены товаров для конечного потребителя, на стадии прохождения сельскохозяйственного сырья через предприятия перерабатывающей промышленности ${ }^{5}$.

Не являясь плательщиками НДС, сельскохозяйственные организации не перечисляют этот налог в бюджет, поэтому контрагенты по договорам теряют возможность возмещения данного налога из бюджета. В этой связи перерабатывающие предприятия вынуждены осуществлять закупку сельскохозяйственной продукции с использованием целого ряда посредников, которые очень часто приобретают продукцию у производителей по нелегальным схемам. Ситуация складывается таким образом, что продукция организаций и предпринимателей, перешедших на уплату ЕСХН, оказывается менее конкурентоспособной, чем аналогичная продукция сельскохозяйственных товаропроизводителей, применяющих обычную систему налогообложения.

Выиграть от перехода на ЕСХН могут лишь те производители, контрагенты которых также не возмещают НДС в соответствии с законом (население, субъекты малого предпринимательства, применяющие льготные режимы $)^{6}$.

Несмотря на то, что в целом гл. $26.1 \mathrm{HK}$ РФ обеспечивает более благоприятные условия налогообложения для сельско-

\footnotetext{
5 Тюпакова Н.Н., Бочарова О.Ф. / Налогообложение сельскохозяйственных товаропроизводителей требует совершенствования // Бухучет в сельском хозяйстве. 2009. - №4.

${ }^{6}$ Проблемы применения ЕСХН // Бухучет в сельском хозяйстве. -2009 . - №6.
} 


\section{Налоги и налогообложение - №2(104) • 2013}

хозяйственных производителей, единый сельскохозяйственный налог так и не стал универсальным для предприятий сельского хозяйства.

Основной причиной того, что большая часть сельскохозяйственных производителей не перешла на использование единого сельскохозяйственного налога, является неоднородность сельскохозяйственных производителей. Значительную часть продукции отрасли производят крупные сельскохозяйственные производители. В то же время отдельные положения гл. 26.1 НК РФ являются более выгодными для использования мелкими хозяйствующими субъектами, в частности:

- освобождение от исполнения налоговой обязанности по НДС является преференциальным для сельскохозяйственных производителей, реализующих свою продукцию физическим лицам; розничная торговля является прерогативой мелких хозяйствующих субъектов;

- критерием применения единого сельскохозяйственного налога является доля выручки от реализации сельскохозяйственной продукции в размере $70 \%$ от общей величины выручки; крупные сельскохозяйственные организации редко соответствуют данному критерию, поскольку их деятельность не является строго специализированной, для таких организаций свойственна диверсификация деятельности․

При общем режиме налогообложения по налогу на прибыль организаций для сельскохозяйственных товаропроизводителей, не перешедших на уплату единого сельскохозяйственного налога, установлены льготные ставки по деятельности, связанной с реали-

\footnotetext{
7 Тюпакова Н.Н., Бочарова О.Ф. / Налогообложение сельскохозяйственных товаропроизводителей требует совершенствования // Бухучет в сельском хозяйстве. 2009. - №4.
}

зацией произведенной ими сельскохозяйственной продукции, а также с реализацией произведенной и переработанной данными организациями собственной сельскохозяйственной продукции.

В настоящее время (с 2013 г) действие нулевой ставки по налогу на прибыль организаций для сельскохозяйственных товаропроизводителей, не перешедших на уплату единого сельскохозяйственного налога применяется бессрочно.

При реализации иной продукции, а также выполнении работ, оказании услуг и реализации, имущественных прав сельскохозяйственные товаропроизводители обязаны исчислять налог на прибыль в полном объеме. Но поскольку большинство хозяйств являются убыточными и не платят налог на прибыль, переход на уплату ЕСХН в ближайшем будущем не сулит им выгод в виде экономии на налоге на прибыль организаций.

Высокорентабельным предприятиям АПК, специализирующимся исключительно на производстве сельскохозяйственной продукции и ее последующей переработке общий режим налогообложения более привлекателен, так как с 2013 г. ставка налога на прибыль организаций для них равна нулю,.

Глава 30 «Налог на имущество организаций» НК РФ не предусматривает федеральных льгот по налогу на имущество для организаций по производству, переработке и хранению сельхозпродукции. Однако такие льготы могут быть предусмотрены на региональном уровне. Поэтому решение вопроса об экономии на налоге на имущество зависит от конкретных норм соответствующих законов субъектов $\Phi^{8}$.

\footnotetext{
8 Тюпакова Н.Н., Бочарова О.Ф. / Налогообложение сельскохозяйственных товаропроизводителей требует совершенствования // Бухучет в сельском хозяйстве. 2009. - №4.
} 
По транспортному налогу для сельскохозяйственных товаропроизводителей на федеральном уровне предусмотрены льготы. Так, не являются объектом налогообложения тракторы, самоходные комбайны всех марок, специальные автомашины (молоковозы, скотовозы, специальные машины для перевозки птицы, машины для перевозки и внесения минеральных удобрений, ветеринарной помощи, технического обслуживания), зарегистрированные на сельскохозяйственных товаропроизводителей и используемые при сельскохозяйственных работах для производства сельскохозяйственной продукции.

Основной принцип уплаты земельного налога в сельском хозяйстве в отличие от налога на землю несельскохозяйственного назначения в России, как и во всех развитых странах, заключается в том, что ставка налога на землю сельскохозяйственного назначения намного ниже ставки налога на землю несельскохозяйственного назначения. Этот льготный подход к налогообложению земли в аграрном секторе, где земля является основным средством производства, представляет собой важный принцип льготного налогообложения сельского хозяйства.

Налоговые ставки земельного налога в Российской Федерации устанавливаются нормативными правовыми актами представительных органов муниципальных образований и не могут превышать $0,3 \%$ в отношении земельных участков, отнесенных к землям сельскохозяйственного назначения или к землям в составе зон сельскохозяйственного использования в поселениях и используемых для сельскохозяйственного производства. Прочие земельные участки облагаются по ставке $1,5 \%{ }^{9}$.

\footnotetext{
9 Тюпакова Н.Н., Бочарова О.Ф. / Налогообложение сельскохозяйственных товаропроизводителей требует совершенствования // Бухучет в сельском хозяйстве. 2009. - №4.
}

Следует отметить, что сельскохозяйственные товаропроизводители пользуются льготами и при обложении другими налогами. Так, например, предусмотрены определенные преимущества и при обложении водным налогом. Не признаются объектами налогообложения данным налогом забор воды из водных объектов для орошения земель сельскохозяйственного назначения (включая луга и пастбища), полива садоводческих, огороднических, дачных земельных участков, земельных участков личных подсобных хозяйств граждан, для водопоя и обслуживания скота и птицы, которые находятся в собственности сельскохозяйственных организаций и граждан.

Для предприятий, перешедших на уплату единого сельскохозяйственного налога (гл. 26.1 НК РФ), предусмотрен льготный порядок включения стоимости приобретенных основных средств в расходы. Он дает возможность сельскохозяйственным товаропроизводителям окупать затраты, связанные с приобретением основных средств, в более короткие сроки.

Данный порядок формирования расходов для исчисления единого сельскохозяйственного налога способствует заинтересованности предприятий в обновлении основных фондов, как инвестиционная льгота.

Если основные средства сильно изношены и их остаточная стоимость невелика, то предполагаемая экономия на уплате единого сельскохозяйственного налога будет незначительной ${ }^{10}$.

Если налогоплательщики создавали основные средства хозяйственным способом (например, возводили сооружения) или привлекали для их сооружения подрядчиков,

\footnotetext{
${ }^{10}$ Карзаева Н.Н., Медведева Е. / Выбор системы налогообложения сельскохозяйственными предприятиями как фактор финансовой устойчивости // Бухучет в сельском хозяйстве. - 2009. - №9.
} 


\section{Налоги и налогообложение - №2(104) • 2013}

остаточная стоимость таких основных средств не уменьшит налоговую базу по единому сельскохозяйственному налогу. Если основные средства будут созданы хозспособом (или с помощью подрядчиков) в период применения спецрежима, расходы на сооружение этих объектов также не будут учитываться при исчислении налоговой базы по единому сельскохозяйственному налогу. Объясняется это тем, что при исчислении налоговой базы по единому сельскохозяйственному налогу в расходы включаются затраты на приобретение основных средств.

В то же время переход на единый сельскохозяйственный налог будет однозначно выгоден тем аграрным предприятиям, которые в ближайшей перспективе планируют приобретение дорогостоящих основных средств.

Организации, начавшие перечислять единый сельскохозяйственный налог в праве перейти через год на общий режим налогообложения. Однако, во-первых, применяемая в течение ЕСХН амортизация основных средств при общем режиме перестанет быть «ускоренной», вследствие чего возникает необходимость пересчета их остаточной стоимости. Во-вторых, если расходы на приобретение основных средств за период выплаты ЕСХН превысили суммы амортизации, то при переходе на общую систему налогообложения полученная разница будет признана доходом организации. Это ограничивает права эффективно функционирующих хозяйств при смене налоговых режимов.

Организации, применяющие общий режим налогообложения, ведут бухгалтерский учет в общеустановленном порядке. При переходе на уплату ЕСХН организации не освобождаются от обязанности вести бухгалтерский учет в полном объеме. Вместе с тем при переходе на уплату ЕСХН организации обязаны соблюдать требования налогового учета при определении объекта налогообло- жения и налоговой базы (доходы, уменьшенные на величину расходов).

Налоговой базой по единому сельскохозяйственному налогу установлена разница между доходами и расходами» со ставкой в 6\% .

Так, по нашему мнению, на современном этапе развития можно выделить ряд положительных и отрицательных моментов специального режима налогообложения (ЕСXH).

К недостаткам ЕСХН в целом можно отнести следующие. Большие льготы по налогообложению сельского хозяйства привели к тому, что основными платежами сельхозпредприятий государству является НДС и платежи в социальные фонды. По своей природе НДС не может быть включен в ЕСХН. Что касается социальных платежей, то конструкция платежей в фонд социального страхования также не позволяет включить их в единый налог. Таким образом, полной консолидации всех налогов и платежей все равно не достигается.

Еще один недостаток ЕСХН заключается в невозможности регулировать отдельные процессы в производственной сфере с помощью данного налога. ЕСХН теряет гибкость, присущую разветвленной системе налогообложения, и усложняет учет.

Наряду с недостатками необходимо выделить и положительные факторы данного режима: уменьшается количество начисляемых и уплачиваемых налогов; сокращается сумма уплачиваемых налогов для слабых и средних хозяйств; оптимизируются сроки уплаты налога (учитывая то, что первое полугодие является затратным, ЕСХН будет уплачиваться раз в год); создается принцип добровольности выбора налогового режима.

Таким образом, на наш взгляд, сравнение преимуществ и недостатков перехода на единый сельскохозяйственный налог свидетельствует о том, что вопрос о целесообразности применения общего или специального режима налогообложения продолжает оставаться дискуссионным. 
Постоянная корректировка законодательных актов не способствует стабильности в работе сельскохозяйственных товаропроизводителей и не заинтересовывает их в эффективности производства. Сохранение значительного количества нормативноправовых документов, регламентирующих налоговую и бухгалтерскую деятельность хозяйствующего субъекта приводит к тому, что по прежнему остается актуальным вопрос об уменьшении количества налогов, приведение их к единым налоговым базам, дифференциации налоговых ставок с учетом специфических особенностей отрасли.

Представляется, что совершенствование налогообложения сельскохозяйственных товаропроизводителей позволит создать в России конкурентоспособное эффективное производство продовольствия.

\section{Библиография:}

1. Карзаева Н.Н. / Новый порядок расчетов с фондами страхования в 2010 году // Бухучет в сельском хозяйстве. - 2009. - №11.

2. Карзаева Н.Н., Медведева Е. / Выбор системы налогообложения сельскохозяйственными предприятиями как фактор финансовой устойчивости // Бухучет в сельском хозяйстве. - 2009. - №9.

3. Проблемы применения ЕСХН // Бухучет в сельском хозяйстве. - 2009. - №6.

4. Тюпакова Н.Н., Бочарова О.Ф. / Налогообложение сельскохозяйственных товаропроизводителей требует совершенство- вания // Бухучет в сельском хозяйстве. - 2009. - №4.

5. Улезько О.В., Деревенских М.Н., Оробинский А.С. Региональные и местные налоги: учебное пособие. - Воронеж: ФГОУ ВПО ВГАУ, 2007. - 167 c.

6. Щербинина М.М. / Об обложении налогом на прибыль сельскохозяйственных товаропроизводителей // Налоговый вестник. - 2008. - №11.

\section{References (transliteration):}

1. Karzaeva N.N. / Novyy poryadok raschetov S fondami strakhovaniya v 2010 godu // Bukhuchet v sel'skom khozyaystve. - 2009. - №11.

2. Karzaeva N.N., Medvedeva E. / Vybor sistemy nalogooblozheniya sel'-skokhozyaystvennymi predpriyatiyami kak faktor finansovoy ustoychivosti // Bukhuchet v sel'skom khozyaystve. - 2009. - №9.

3. Tyupakova N.N., Bocharova O.F. / Nalogooblozhenie sel'skokhozyaystven-nykh tovaroproizvoditeley trebuet sovershenstvovaniya // Bukhuchet v sel'skom khozyaystve. - 2009. - №4.

4. Ulez'ko O.V., Derevenskikh M.N., Orobinskiy A.S. Regional'nye i me-stnye nalogi: uchebnoe posobie. - Voronezh: FGOU VPO VGAU, 2007. - 167 s.

5. Shcherbinina M.M. / Ob oblozhenii nalogom na pribyl' sel'skokhozyayst-vennykh tovaroproizvoditeley // Nalogovyy vestnik. - 2008. - №11. 